\title{
SPEARHEADING DEVELOPMENT THROUGH EMPOWERING SMALLHOLDER FARMERS ALONG Beef Cattle Value Chains: A Case OF GoromonZi AND MurehWA Districts, ZIMBABWE
}

\author{
Angeline. Mujeyi ${ }^{1}$, Munyaradzi. Mutenje ${ }^{1,}$ Godfrey. J. Manyawu ${ }^{2}$, \\ Lovemore.Gwiriri ${ }^{2}$, Irenie.Chakoma ${ }^{2}$ \\ 1CIMMYT P.O. Box MP 163, Mount Pleasant, Harare, Zimbabwe \\ 2ILRI c/o CIMMYT P.O. Box MP 163, Mount Pleasant, Harare, Zimbabwe
}

\begin{abstract}
Smallholder beef subsector can potentially contribute to the nation's development. The paper presents the results of the value chain analysis of the beef sub sector in Zimbabwe. Data was gathered through cross sectional household survey of 380 beef farmers, six community focus group discussions, key informant interviews and interviews of value chain actors. Empirical results showed that profitability of beef marketing by farmers is constrained by low productivity caused by longer calving intervals, poor animal husbandry practices and lack of market information. Three existing beef cattle value chains were identified. A total of $91 \%$ of the producers sold cattle to the informal livestock market and only 9\% through formal market. Body condition, health of animal and age were reported as major factors used in setting cattle prices. The study recommends setting up breeding programs, improved husbandry practices, improving farmer access to market information and collective action among farmers.
\end{abstract}

\section{Key words}

Value chain, beef sub sector, marketing margins, Zimbabwe

\section{INTRODUCTION}

Beef is crucial in Zimbabwe and a potential export product. Zimbabwe used to have quotas for beef exports to the European Union (EU) under the Lome Convention [1]. Increased beef production can thus stimulate economic growth, export earnings and development. Livestock systems represent a potential pathway out of poverty for many smallholders in Zimbabwe. An estimated $60-75 \%$ of rural households own cattle, making cattle ownership a significant asset for farmers' lives [2]. In many cases, livestock are a central component of smallholder risk management strategies [3].Smallholders integrate crop and animal production to maximize returns from their limited land and capital, minimize production risk, diversify income sources, provide food security, and increase productivity [4]. Livestock production is crucial to smallholder farming systems, livelihoods and for boosting economic growth of the agro-based economies [5]. Livestock production support crop production through provision of draft power and manure, and capital to buy inputs. Increased access to draft power gives farmers the opportunity to cultivate and plant early. Despite over $60 \%$ of rural farmers in Zimbabwe owning cattle, only a few can market their cattle due to low productivity and lack of market oriented production. If the contribution of cattle to food security and income generation for smallholder 
farmers is to grow, a comprehensive evaluation of the value chain, as well as the factors that affect competitiveness within the different levels of the value chain is necessary.

\subsection{Problem Statement and Justification}

In order to raise smallholder incomes in Zimbabwe, there is need to help farmers become more productive and competitive in other agriculture commodities other than crops like horticulture crops, maize and tobacco. Smallholder farmers have an opportunity to commercialise beef production particularly in Goromonzi and Murehwa. These are strategic districts located in natural region II which is away from foot and mouth diseases infected zones [6]. Though studies have highlighted opportunities and challenges faced by cattle farmers, there is no complete tracking of beef marketing margins along the value chain. For Zimbabwe, where smallholder farmers are faced with land constraints but own cattle in a country currently experiencing beef shortages, understanding price dynamics is important in order to maximise farmer profitability. Against this backdrop, the purpose of this paper is to conduct a value chain analysis of smallholder beef cattle production and marketing in Goromonzi and Murehwa. The study mapped the current value chain and identified challenges and opportunities for up scaling for smallholder farmers.

\section{Over View Of Beef Cattle Production In Zimbabwe}

Recent statistics show that cattle for 2013/14 were 5,368,105, a $2 \%$ increase from 5,241,192 of 2012/13 [7].Communal farmers own $69 \%$, A1 farmers $11 \%$, small scale commercial farming areas $4 \%$, A2 and large scale commercial farmers $10 \%$ while the old resettlement areas account for about $6 \%$. Thus, about $90 \%$ of the cattle in Zimbabwe are owned by the smallholder sector which has ramifications for the beef industry because to smallholder farmers, cattle play various functions besides commercial beef slaughter. In addition, with very low take off rates of about $3 \%$ in 2012, the smallholder farmers could only supply 44442 tons against a 15\% national target [8]. Further evidence shows that although national herd has been constant, the number of slaughtered animals has declined over the past few years to a monthly average of about 20000 head from an average of 32 400during the 1990s [9].The beef cattle sub-sector is an important source of meat in the country. For instance, using data from the recent Poverty, Income, Consumption and Expenditure Survey by ZIMSTATS, the LMAC has revealed very low levels of animal protein consumption in Zimbabwe. Of the $\$ 745$ annual per capita expenditure in Zimbabwe during 2011-2012, food accounted for \$246 (33\%), of which \$74 (30\%) was spent on animal products. Beef accounts for the highest expenditure on livestock products at $35 \%$, followed by poultry products $(32 \%)$, fish products $(17 \%)$, milk products $(12 \%)$, pork products (3\%), sheep and goats $(2 \%)$, and game meat $(0.2 \%)$ [9]. The potential of the beef cattle sector in the study districts can be fully recognized if constraints currently faced are identified.

\section{Methodology}

\subsection{The study area}

The study was conducted in two districts namely Goromonzi and Murehwa which are located in Mashonaland East province in agro ecological region II. Natural Region (NR) IIa and IIb are characterised by reliable high rainfall patterns ranging of between 720 to $1000 \mathrm{~mm}$ per annum and are suitable for intensive cropping and livestock production. Soil types in the districts range from deep sandy soils, sand loamy to deep red clay soils. The average farm size in Murehwa per 
household is 3.43 acres. Seventy five percent of the total land area is put under maize, $15 \%$ under groundnuts and $5 \%$ under sweet potatoes during the summer season. The average farm size land owned in Goromonzi is 3.5 acres ( 1.4 ha) with $85 \%$ being put under maize, $5 \%$ under groundnuts and 5\% under other crops. The economy of the Goromonzi and Murehwa is dominated by smallholder agriculture. Horticulture and dry land field crop production dominate while livestock rearing is the third leading economic activity of the majority of the farmers in these districts.

\subsection{Data collection methods}

Data collection was done through household survey, key informant semi structured interviews, focus group discussions (FGDs) and observation and in-depth interviews of stakeholders along the beef value chain. A checklist was designed and used in guided conversations during community focus group discussions. The Focus group discussions involved farmers discussing livelihood strategies in their wards and actors along the beef value chains that they are currently involved with. A total of six (6) FGDs were conducted .Focus group discussions were followed by survey of identified value chain actors. A formal cross-sectional survey was carried to collect primary data from 380 beef cattle farmers in 2 the districts. A structured questionnaire was used after being pre-tested and was administered through direct interviews among selected sample farmers.

A multi-stage sampling technique based on districts, wards and villages was used. Selection of farmers was random from the list of cattle farmers supplied by the village heads. Quantitative data in the questionnaires assessed patterns, trends and relationships among different value chain actors. The questionnaires focused on what value chain actors are doing, volumes and types of different commodities traded, pricing mechanisms, membership to associations and constraints and challenges faced by these actors. Key informant interviews were held with key personnel from governments departments Livestock Production and Development (LPD), Agricultural Technical and Extension Services (AGRITEX) and field officers from NGOs working in the 2 districts i.e. (CADS) and Community Technology Development Organisation (CTDO). Secondary data was also collected from ZIMSTAT and FAOSTAT.

\subsection{Analytical Framework}

The study used the value chain approach to analyse data. Researchers have used the Value chain approach to analyse conducts and performance of the indigenous beef sector. [10] [11] A study in Lake Victoria Basin used the value chain approach. The study found out that the beef value chain suffered from limited access and linkages to premium markets, lack of entrepreneurial dynamisms by actors, as well as, use of poor production and processing technologies. Another study in Tanzania using the value chain approach found out that the supply chain was characterized by low value addition among the pastoralist and high value addition among the beef cattle fatteners.

A combination of quantitative and qualitative research techniques were used in this value chain approach. The value chain approach analyses the flow of commodities and linkage among actors of a specified sub-sector and contributes to the identification of opportunities and constraints of a particular value chain for its growth. This approach has been widely applied by non-governmental organizations and research institutes in agriculture and rural development throughout the world [12]. The functional analysis was used to define the actors in the value chain. This was done through mapping. Different players and their roles in the chain were identified and maps were drawn to show the actors at different stages of the value chain. In addition, quantities of goods 
traded and the prices involved were discussed as well as challenges that they currently face as they perform their operations along the value chain. The value chain map is a visual representation of the structure and illustrates the way in which beef cattle and their products flow from production in the study areas to end markets and how the overall beef cattle sector operates. Marketing functions are represented on a vertical axis on the left hand side of the diagram and the existing actors are represented using boxes with solid outlines. The potential or missing channels linkages are represented by dotted lines. The product flows are represented by arrows. As a product move from one actor to another, value is added to the product. The Cattle to meat value chain consists of input suppliers (stock feed, breeding animals, semen, embryos, veterinary supplies and other ancillary service), farmers, and traders, processors (butcheries and consumers). Value chain analysis therefore sheds light on the size of the firms participating in each link, how they are participating or could be participating in the chain, and opportunities to facilitate or improve those linkages.

\section{Results And Discussion}

\subsection{The beef cattle markets and marketing channels}

Smallholder farmers in Goromonzi and Murehwa districts market beef cattle through informal and formal markets. The former consists of individuals buying cattle from farmers for different reasons which include slaughter, as an investment or for social functions such as funerals, customary celebrations. The formal channel is when farmers sell cattle directly to butcheries, auctions, feedlot owners and abattoirs. Individual traders dominate the beef value chain in the informal sector. Urban households (HH) buy beef meat from butcheries or directly from abattoirs. Figure 1 gives a map on the flow of beef among the smallholder farmers in Murehwa and Goromonzi. 


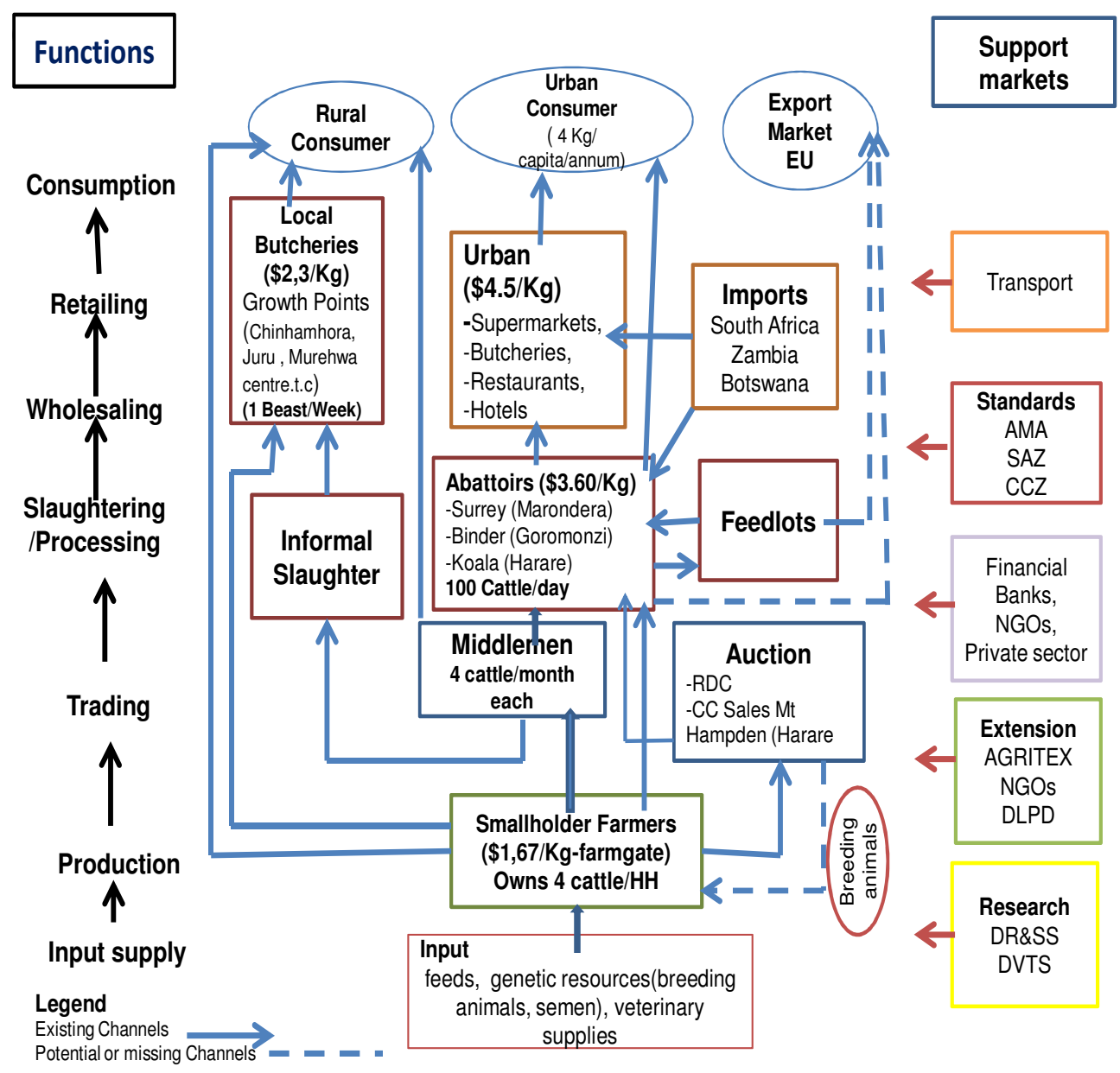

Figure 1: The Beef Sub sector map

Three main beef channels can be distinguished in Goromonzi and Murehwa (Figure 1). The first one is the domestic butchery chain. Farmers sell to local butcheries directly or through agents. Local butcheries buy cattle and slaughter then sell directly to households especially in the rural and peri-urban areas. Farmer's gets lower prices through this channel as there are no grading standards set and transactions are based on negotiations. The second channel is the farmer to urban middlemen channel. The urban middlemen then sell to abattoirs like Koala and Surrey. These middlemen in some cases work with local marketing agents. The livestock marketing agents are facilitators bringing together buyers and sellers and they function on a commission basis. The study found out that they are paid $\$ 10$ to $\$ 20$ for any beast identified and successfully secured for the middlemen. The third channel is the farmer to abattoir channel. The abattoirs have grades set aside but few farmers market through this channel. This is because most of the farmers are not prepared to invest time in organising transport to take the animals to the towns where the abattoirs are located. The butcheries indicated that they get most of their beef from smallholder farmers (90\% in Goromonzi and $83 \%$ in Murehwa). The other beef meat is obtained from abattoirs in nearby cities like Harare. Sixty and $80 \%$ of the butcheries in Goromonzi and Murehwa respectively indicated that December was the month of peak sales followed by November for Goromonzi and January for Murehwa. Smallholder farmers who sell in January usually do so to generate income for payment of school fees as the first school term starts. 
December experiences more sales since this is the time of the festive season when people celebrate Christmas. A minor channel is when livestock are bought for slaughter, investment or social functions such as weddings, funerals, customary and religious celebrations by fellow smallholder farmers in the districts.

\subsubsection{Producers}

Smallholder farmers own an average of 4 beef cattle with a range of 1 to 25 . Sixty-seven percent of the beef/draft cattle reared is Mashona breed and the minority consists of the Afrikaner, Brahman and crossbreeds. Cross breeds and Brahmans are more prominent in Murehwa than in Goromonzi. The Mashona breeds are more resilient and more adapted to the local conditions and this explains their popularity. Smallholder farmers keep livestock for various purposes such as provision of draught power, manure, milk, meat, as a symbol of wealth, for use in socio cultural functions such as dowry payment and appeasement of ancestors and income generation in times of shocks like funeral or droughts.

\subsubsection{Cattle Production System}

The extensive cattle production system is the common system because of its low costs of investment. Cattle are kept out-doors and on pasture all the time. The length of lactation period in the two project site for beef cattle ranged from 8 to 12 months, while calving interval varied from 15 to 20 months. Cattle performance measured by age at first calving seems to be better in Murehwa district with an average age of 27 months compare to 36 months of Goromonzi district.Wetlands and forests are the most commonly widely used grazing rangelands to feed cattle on in the study areas. Wetlands are more common in Goromonzi whereas forest grazing rangelands are by far the most important rangeland type in Murehwa as reported by $39 \%$ and $45 \%$ cattle keeping households. A sizable percentage of the farmers (about 10\%) also feed their animals on stored residues of maize and small grains and legumes. Most farmers do not own bulls for cattle breeding purposes and breeding is uncontrolled. The few available bulls are in most cases overused. The main challenges sited by farmers during focus group discussions for the limited use of commercial concentrate were affordability and availability of maize grain to mix with the concentrate given that a higher proportion of the farmers were failing to meet household food needs.

\subsubsection{Small and Large traders}

Small traders in the rural areas consist of middlemen and butcheries. Butcheries buy live animals which they slaughter to sell. Middlemen sell to butcheries or abattoirs in nearby Harare and Marondera towns. The middlemen in some cases recruit agents who act like local errand boys/informants, sourcing and mobilizing cattle from the farmers on behalf of the middlemen. These get paid $\$ 10$ for every beast they identify and secure for the middlemen. There are also beef committees in the rural areas. Beef Committees are groups of mainly civil servants like teachers, police; extension officers and nurses who buy beasts for slaughter as a group from the farmers. . Large traders for beef cattle in the 2 districts are mainly the abattoirs. Three abattoirs namely Koala, Binder and Surrey buy cattle from smallholder farmers. Few farmers (about 10\%) in Murehwa also market to abattoirs like Surrey in Marondera, Koala in Harare and Binder in Goromonzi. The rural District Councils (RDC) used to run sale pens but this public auction system is no longer functional. Currently the RDCs carry auctions for stray animals only. 


\subsubsection{Processing}

The abattoirs and butcheries are responsible for processing. They slaughter the animals into different grade portions. Products like mince, sausage are also processed. The abattoirs then supply butcheries in towns and supermarkets. Currently, Goromonzi farmers have access to 3 abattoirs i.e. Binder in Goromonzi districts, Surrey in Marondera and Koala in Harare. They slaughter cattle and also keep some small herd for feeding before slaughter. Koala abattoir also has butchery, Koala Park Butchery, which sells affordable meat, including beef, chicken and pork, and many Harare and Chitungwiza residents flock to the park to buy the meat, as it is cheap compared to other butcheries in Harare. Koala Park also supplies beef to many butcheries around Harare. Surrey is located $55 \mathrm{Km}$ along the Harare -Mutare highway. Abattoirs generally have capacity to slaughter 100 head of cattle per day. Surrey also runs some feedlots to augment supplies that they get from deliveries by farmers. They slaughter and supply meat to wholesale customers in various towns in Zimbabwe. Binder abattoir is located in Goromonzi and provides slaughter services at a cost of $\$ 30 /$ head of cattle. The abattoir buys live animals or provides slaughter services depending on client's desires. Binder abattoirs have also been involved in helping farmers by donating pedigree bulls to communities in order to boost the indigenous breeds.

\subsubsection{Regulating the Beef Value chain}

Government through the Ministry of Agriculture, Mechanisation and Irrigation Development (MAMID) regulates the livestock industry. Research and extension services are provided through the Division of Livestock and Veterinary Services (DLVS), Livestock Production and Development (LPD) and the Livestock Research Division of the Department of Research and Specialist Services (DR\&SS). If farmers sell at an auction, the RDC charges $10.5 \%$ of the sale price as levy. The Zimbabwe Republic Police (ZRP) Anti Stock Theft Unit offer police clearance services for livestock intended for sale or slaughter after clearance and certification by the DLVS for animal health purposes. The buyers and processors such as abattoirs are regulated by Agricultural Marketing Authority (AMA).

\subsection{Traits and factors that determine the price of livestock}

The understanding farmers have of traits and factors that affect price of livestock plays a crucial role in their decisions regarding the structure and composition of the livestock enterprise. There was heterogeneity in the farmers' ranking of the determinants of cattle price. Goromonzi farmers identified body condition, age and health of the animal in their order of importance as the key determinants of price, while the Murehwa farmers identified health, body condition of the animal and sex of the animal as the three most important attributes sort by beef cattle buyers. 
International Journal of Managing Value and Supply Chains (IJMVSC) Vol. 6, No. 4, December 2015

Table 1: Attributes and factors influencing cattle prices in Goromonzi and Murehwa ranked according to importance Source: Survey results.

\begin{tabular}{|c|c|c|c|c|c|c|}
\hline District & $1^{\text {St }}$ attribute & $\% \mathbf{H H}$ & $\begin{array}{l}2^{\text {nd }} \\
\text { attribute }\end{array}$ & $\% \mathbf{H H}$ & 3rd Attribute & $\% \mathbf{H H}$ \\
\hline \multicolumn{7}{|c|}{ Farmers' ranking of the cattle attributes buyers look for } \\
\hline $\begin{array}{l}\text { Goromonz } \\
\mathrm{i}\end{array}$ & Age & 38. & $\begin{array}{l}\text { Body } \\
\text { condition } \\
\& \text { breed }\end{array}$ & 47. & $\begin{array}{ll}\begin{array}{l}\text { Free } \\
\text { disease }\end{array} & \text { from } \\
\end{array}$ & 33 \\
\hline Murehwa & Disease free & 33 & $\begin{array}{l}\text { Body } \\
\text { condition }\end{array}$ & 35 & Sex of animal & 31 \\
\hline \multicolumn{7}{|c|}{ Factors determining Cattle prices } \\
\hline District & 1st factor & $\% \mathbf{H H}$ & $\begin{array}{l}\text { 2nd } \\
\text { factor }\end{array}$ & $\% \mathbf{H H}$ & $3^{\text {rd }}$ factor & $\% \mathbf{H H}$ \\
\hline $\begin{array}{l}\text { Goromonz } \\
\text { i }\end{array}$ & $\begin{array}{l}\text { Body } \\
\text { condition }\end{array}$ & 46. & Age & 35 & Breed & 47 \\
\hline Murehwa & Weight & 50. & $\begin{array}{l}\text { Body } \\
\text { condition }\end{array}$ & 24 & Sex of animal & 25 \\
\hline
\end{tabular}

Factors determining cattle price in Goromonzi included body condition, age and breed whereas in Murehwa live weight, body condition and sex of the animal influenced price.

\subsection{Transaction types and Marketing margins}

Cattle are sold for cash and in some cases farmers exchange aged cattle for heifers or younger stock with some options for cash top up. Producer (farm gate) prices paid to farmers per beast range from as low as US\$200 to a high of US\$300 on average in the 2 districts when selling through local butcheries and middlemen. However, abattoirs pay between US\$500 and US $\$ 900$ for the same beast depending on the grade. The traders make profits margin of around $50 \%$ when they sell to abattoirs and butcheries who consider grades and charge per kg. During years of famine cattle can be exchanged for grain or food items. The Rural District Councils (RDCs) periodically run public auctions for stray livestock. Council charges $10,5 \%$ of the sale prices as levy to farmers who choose to sell through the RDC sell pens. In addition, farmers pay between $\$ 2$ and $\$ 10$ for police and veterinary department clearances if they are to sell to abattoirs. Buying arrangements in the 2 districts are affected by the level of competition in the area. There are more butcheries in Goromonzi and $40 \%$ of them indicated that they consulted other traders on their prices and then determined their own price from there. About $10 \%$ use a cost plus margin approach while $50 \%$ revealed that they just determined their prices without consultation. When the butcheries purchase from the farmers, farmers get cash (more than $80 \%$ ) in the 2 districts and very few transactions (10\% in Goromonzi and 17\% in Murehwa) are on a forward contract basis where the farmer is paid after the slaughtered beast is sold. 


\subsection{Economic analysis}

Researchers have pointed out that the challenge to livestock farming in communal areas is making use of marketing channels that offers the best cattle prices and hence highest returns [13]. Such decisions require reliable information about cattle prices, the right selling time, the channels available, cattle breeds and the age of cattle that give the highest returns. Gross margin analysis was done for producers to show what they get along different marketing channels. Gross margin is computed as the value of output (benefits are values of meat produced, manure, transport services, tillage services etc.) less the variable costs attributed to it. Profitability of beef cattle keeping was done to show the incremental benefits when they sell at 3 different markets i.e. farm gate, to local butcheries or to abattoirs in towns. The types of costs that are commonly incurred by beef cattle producers include; labour for herding, drugs and vaccines, veterinary annual subscriptions used to access dipping services, maintaining the kraal and transport and permit when they market. Farmers indicated that oxen are normally sold when they are 7 years or older. Benefits from cattle included tillage services (ploughing and weeding), manure generation, transport services (fetching water, firewood and maize to the grinding mill for processing) and income when they are sold. 
International Journal of Managing Value and Supply Chains (IJMVSC) Vol. 6, No. 4, December 2015

Table 2: Farmer Level analysis: Selling to various actors (Per live animal)

\begin{tabular}{|c|c|c|c|c|c|}
\hline \multirow[b]{2}{*}{ Benefits } & \multicolumn{5}{|c|}{ Marketing channel } \\
\hline & Description & $\begin{array}{l}\text { Farm } \\
\text { gate }\end{array}$ & $\begin{array}{l}\text { Local } \\
\text { Middlemen }\end{array}$ & $\begin{array}{l}\text { Local } \\
\text { Butchery }\end{array}$ & Abattoir \\
\hline Manure (carts) & $\begin{array}{l}1.5 \text { carts per } \\
\text { year@ } \$ 30 / \text { cart } \\
\text { for 7years }\end{array}$ & 315 & 315 & 315 & 315 \\
\hline Ploughing & $\begin{array}{l}2 \text { Ha yearly (pair } \\
\text { of oxen @ } \$ 40 / \mathrm{ha} \\
\text { for } 4 \text { years) }\end{array}$ & 160 & 160 & 160 & 160 \\
\hline Carcass & $\mathrm{Kg}$ & 150 & 150 & 150 & 150 \\
\hline Carcass selling price & $\$$ & 1.67 & 2.00 & 2.33 & 3.6 \\
\hline Fifth quarter & $\$$ & 0.00 & 0.00 & 0.00 & 60 \\
\hline Cattle revenue & $\$$ & 250 & 300 & 350 & 540 \\
\hline $\begin{array}{l}\text { Transport (Transporting } \\
\text { farm produce, Firewood } \\
\text { and water collection) }\end{array}$ & $\begin{array}{l}@ \$ 50 / \text { annum } \\
\text { for } 4 \text { years }\end{array}$ & 200 & 200 & 200 & 200 \\
\hline \multicolumn{2}{|l|}{ Total Benefits } & 925.00 & 975.00 & 1025.00 & 1275.00 \\
\hline \multicolumn{6}{|l|}{ Costs } \\
\hline Labour (herding) & $\begin{array}{l}\text { e.g. US } \$ 10 \text { per } \\
\text { month for } 7 \\
\text { years }\end{array}$ & 840 & 840 & 840 & 840 \\
\hline yearly dipping fees & $\begin{array}{l}\text { US\$2 per head } \\
\text { per annum for } 7 \\
\text { years }\end{array}$ & 14 & 14 & 14 & 14 \\
\hline Dosing & $\begin{array}{ll}2 & \text { Doses/year } \\
@ \$ 3 & \end{array}$ & 42 & 42 & 42 & 42 \\
\hline Transport fees & to market & 0 & 0 & 0 & 50 \\
\hline Kraal repairs & $\$$ & 21 & 21 & 21 & 21 \\
\hline $\begin{array}{l}\text { Movement permit \& } \\
\text { Police Clearance }\end{array}$ & $\$$ & 0 & 10 & 10 & 10 \\
\hline Rural District council levy & 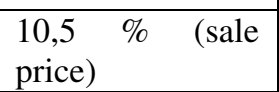 & 0 & 0 & 0 & 56.5 \\
\hline Slaughter fees & $\$$ & 0 & 0 & 0 & 30 \\
\hline \multicolumn{2}{|c|}{ Total Variable Costs (TVC) US\$ } & 917 & 927 & 927 & 1063.6 \\
\hline \multicolumn{2}{|c|}{ Gross Margin (Total Benefits-TVC) US\$ } & 8 & 48 & 98 & 211.4 \\
\hline
\end{tabular}

Firstly the results of analysis of the profit margins at the producer level suggest that returns are greater if cattle are sold at abattoirs compared to selling locally within the district as shown by $\$ 8$ gross margin obtained at farm gate against $\$ 211.4$ when sold at abattoirs. This is normally because they are no grading set up by middlemen or local butcheries. Price is based on negotiations. The cattle usually fall in the economy and manufacturing grades at the abattoirs and there is room for smallholder farmers to improve the grade to higher levels like super and choice through marketing cattle when they are still young and supplementary feeding of the cattle using even cheaper home processed feeds from the mucuna and lablab that they have started growing over the last 2 years. Any opportunity also exists for abattoirs to buy even young cattle from farmers for pen fattening in their feedlots in order to increase the cattle production country wide. 




Figure 2: Cattle beef price discovery

Secondly, the price discovery mechanism for live animals (at the farm-gate) plays a significant role in determining profitability and competitiveness for the farmer. Many farmers sell their live beef animals on an un-organized individual basis. In this case, they are often offered lower prices. Data from the survey shows that there is a significant difference between individual farm gate and the prices at abattoirs.

\subsection{Challenges to Cattle input and output markets}

The smallholder cattle beef sector in still faces major challenges that continue to constrain its competitiveness.

Table 3: Challenges and opportunities along the smallholder beef value chain

\begin{tabular}{|c|c|c|c|}
\hline $\begin{array}{l}\text { Value Chain } \\
\text { Level }\end{array}$ & Strengths & Weaknesses & Intervention Activities \\
\hline Inputs & Input market available & $\begin{array}{l}\text { High input costs (drugs } \\
\text { and } \quad \text { supplementary } \\
\text { feeds ) }\end{array}$ & $\begin{array}{l}\text { Setting up credit schemes to } \\
\text { support beef value chain. }\end{array}$ \\
\hline Production & $\begin{array}{l}\text { Government is committed } \\
\text { to developing the sector. } \\
\text { There are Officers who are } \\
\text { ward based from LPD to } \\
\text { give extension advice. } \\
\text { Indigenous breeds that are } \\
\text { resistant to drought and } \\
\text { most diseases }\end{array}$ & $\begin{array}{l}\text { Shortage of grazing } \\
\text { land, low productivity } \\
\text { due to smaller breeds } \\
\text { and longer calving } \\
\text { interval caused by } \\
\text { shortage of bulls } \\
\text { Limited access to } \\
\text { credit }\end{array}$ & $\begin{array}{l}\text { Capacity building farmers on } \\
\text { animal husbandry in order to } \\
\text { increase productivity, } \\
\text { Up scaling pen-fattening using } \\
\text { home grown fodder legumes that } \\
\text { have been promoted by ILRI and } \\
\text { Establishment of Breeding centres } \\
\text { in the districts (to offer pedigree } \\
\text { bulls and artificial insemination } \\
\text { services) }\end{array}$ \\
\hline Marketing & $\begin{array}{l}\text { Government has put in } \\
\text { place legislation to ensure } \\
\text { the excellent beef quality } \\
\text { in abattoirs }\end{array}$ & $\begin{array}{l}\text { Low output prices, } \\
\text { High transaction costs } \\
\text { when they market } \\
\text { beyond the farm gate, } \\
\text { Limited cash to } \\
\text { purchase high volumes, } \\
\text { High cost of credit, } \\
\text { Cumbersome clearance } \\
\text { process, of market } \\
\text { Lack formal } \\
\text { information, } \\
\text { Absence of forma } \\
\text { auction marketing } \\
\text { systems }\end{array}$ & $\begin{array}{l}\text { Reactivate export of beef to other } \\
\text { countries, } \\
\text { Promote coordination and } \\
\text { information sharing by all } \\
\text { stakeholders along value chains } \\
\text { and } \\
\text { Improve beef quality taken to the } \\
\text { market }\end{array}$ \\
\hline
\end{tabular}


The farmers also get particularly when they sell locally and have high transaction costs which reduce their profit margins. Access to market information is also limited. There is need to make use of mobile phones to send relevant market information. AGRITEX can partner with ECO Farmer to supply them with the relevant technical and market information for boosting cattle productivity. Cattle farmers indicated that they access market information from extension workers, fellow farmers, and traders who sometime operate as brokers and butchers as well as the ECO Farmer short messaging services (SMS) facility run by mobile service provider ECONET.

\section{Policy Implications}

\subsection{Implications for smallholder Cattle beef producers}

The average smallholder farmers have limited stock averaging 4 cattle or less which are kept under traditional system. These farmers are land constrained, lack a proper breeding program and are faced with decreasing grazing lands due to the growing population. The study found out that smallholders have some potential to keep livestock but there remains need for an integrated system with other potential actors along the value chain. The smallholder farmers can be capacitated to buy stock from fellow smallholder farmers and pen fatten the cattle in feedlots for selling to abattoirs and even potentially exploring the export market. Introduction of breeding programs through artificial insemination or use of per-degree bulls will go a long ways in shortening the longer calving interval and improving the cattle breed. The farmers can benefit production and processing home-grown feeds from mucuna and lablab and the cattle can quickly be off loaded to the commercial farms for pen fattening. The abattoirs could also increase uptake of cattle for feeding in feedlots. There is great potential for poor, small-scale producers to take advantage of the opportunities presented by the growing demand for meat. Potential Interventions (collective action, district auction systems), setting up breeding programs for farmers (AI centres in each province)

Given the current challenges, there is need to organize farmers to better access improved services i.e. better breeds, better feeding systems, veterinary services and marketing through privatepublic sector partnerships.. Formation of cattle marketing groups to lower transaction costs and increase access to market information is highly recommended.

\section{ACKNOWLEDGEMENTS}

The authors are gratefully to beef value chain actors for their collaboration during the study. Support of the government of Zimbabwe through the Ministry of Agriculture, Mechanization and Irrigation Development (MAMID) working with departments (AGRITEX, DLVS) is highly acknowledged. We also recognize the cooperation and assistance provided by partners in the project i.e. ILRI, ICRISAT, CADS, and CTDO. The supportive role provided by CIMMYT and ILRI is greatly acknowledged. This study was funded by Australian Centre for International Agricultural Research (ACIAR). 


\section{REFERENCES}

[1] Sartorius van Barch H.J, Van Renen E and Kirsten J.F 1998 Supply Response , Demand, and Stocks for Southern African beef. Working paper. Department of Agricultural Economics,Extension and Rural development. University of Pretoria, Pretoria, South Africa.

[2] Sukume C. and Maleni D. 2012, Constraints to Competitiveness: Beef CIBER Study. ZIMACP. DAI/USAID

[3] Bailey D, Barrett C B, Little P D and Chabari F (1999) "Livestock markets and risk management among East African pastoralists: a review and research agenda". GL-CRSP Pastoral Risk Management Project Technical Report No. 03/99. Utah State University.

[4] Paris, T.R. 2002. Crop-animal Systems in Asia: Socio-economic benefits and impacts on rural livelihoods. Agricultural Systems 71(1-2): 147-168.

[5] McDermott, J.J., Rondolph, T.F. and Staal, S.J. (1999). The economics of optimal health and productivity in smallholder livestock systems in developing countries. Scientific and Technical Review of the Office International des Epizooties, 18(2):399-424.

[6] Mavedzenge, B.Z., Mahenehene, J., Murimbarimba, F.,Scoones, I and Wolmer, 2006, Changes in the Livestock Sector in Zimbabwe Following Land Reform: The case of Masvingo Province.

[7] Ministry of Agriculture, Mechanisation and Irrigation Development (cited as MAMID, 2014). First Round Crop and Livestock Assessment Report. Government of Zimbabwe.

[8] Livestock Production and Development (cited as LPD, 2012). Monthly reports, Ministry of Agriculture, Mechanisation and Irrigation Development,Harare,Zimbabwe

[9] Livestock and Meat Advisory Council (cited as LMAC, 2013). Combined Symposium held by the Stockfeed Manufacturers Association, Zimbabwe Poultry Association and Pig Producers Association of Zimbabwe at ART Farm, 22- 23 May 2013. Report prepared by Dr C. Sukume.

[10] Mlote SN, Mdoe NSY, Isinika A, Mtenga LA (2012). Value addition of beef cattle fattening in the Lake Zone in Tanzania: Challenges and opportunities. Livestock Research for Rural Development. $24: 6$.

[11] Kadigi RMJ, Kadigi IL, Laswai GH, Kashaigili JJ (2013). Value chain of indigenous cattle and beef products in Mwanza region, Tanzania: Market access, linkages and opportunities for upgrading. Acad. J. Agric. Res. 1(8): 145-155.

[12] FAO,(2005) Constructing Commodity Chain Functional Analysis and Flow Charts. Food and Agriculture Organisation of the United Nations,Rome,Italy

[13] Benson, G., Miller, D. \& Lichtenwalner, R. (2001) Beef cattle marketing in North Carolina.http://www2.ncsu.edu/unity/lockers/project/arepublication/AREno32.pdf. 


\section{Authors}

Angeline Mujeyi is a Research Associate in the Socio Economics Program specialising in economic analysis of technologies (conservation agriculture and drought tolerant maize varieties) with CIMMYT, based in Harare, Zimbabwe. She trained as an Agricultural Economist at the University of Zimbabwe. She holds a Masters in Agricultural and Applied Economics and a Bachelor of Science honours Degree from the University of Zimbabwe. She has over eight years' experience working with smallholder farmers on technology adoption and linking farmers to markets with organisations such as International Centre for Tropical Agriculture (CIAT,) Agricultural Research Council (ARC) and Progress!o (Catholic Institute for International Relations).

Munyaradzi Mutenje is an Agriculture Economist, based at CIMMYT in Harare, Zimbabwe.She trained at the University of Zimbabwe. She received her PhD from the University Of Kwazulu Natal South Africa in 2011 and joined CIMMYT thereafter. Her professional andresearch interest focuses on food security, poverty and livelihood analyses, impact assessments and sustainable development. She is involved in four projects on sustainable intensification in southern Africa. She possesses vast experience as extension officer, monitoring and evaluation specialist, lecturer and researcher. She has authored and coauthored more than 10 peer-reviewed publications.

Godfrey Manyawu is an Animal Scientist with over 23 years of experience in ruminant animal production in Zimbabwe. He received his $\mathrm{PhD}$ with the University of Zimbabwe in 2002. The $\mathrm{PhD}$ focused on forage production and Silage Potential of Napier grass and Napier X Pearls millet. Godfrey Manyawu is the ILRI coordinator for a multi-centre project on 'Zimbabwe Crop Livestock Integration for Food Security ZimCLIFS' funded by the Australian Centre for International Research, ACIAR. Special areas of research are the improvement of livestock production and fodder production among smallholder farming communities. He has been actively involved in evaluation of forage technologies diets by smallholder farmers of Zimbabwe. Godfrey has authored and co-authored several publications on livestock. He has guided the research programs of Bsc and MSc students.

Lovemore Gwiriri is a Research Assistant with the International Livestock Research Institute (Southern Africa Regional Office) with research experience in food security, climate change resilience, livelihoods and rural development aspects with particular interests in the interface between crop and livestock integration, market access and capacity building to foster livestock based smallholder farmer resilience. He holds a Masters in Management of Development, Rural Development and Food Security from Van Hall Larenstein, Part of Wageningen University in the Netherlands. He also holds a Bachelor of Science Agriculture honours Degree from the University of Zimbabwe. He has over ten years research for development experience working with smallholder farmers on technology adoption and linking farmers to markets with organisations such as AgriProfocus (Netherlands), Centre for Development Innovation (Netherlands) and Henderson Research Institute.

Irenie Chakoma is a Research Associate based at ILRI, Harare, Zimbabwe. She holds a Master's in Business Administration from the University of Zimbabwe, Bachelor of Science Degree in Agriculture from Larenstein University, Netherlands, Diploma in Agriculture from Chibero Agricultural College, Zimbabwe, and Certificate in Program and Project Monitoring and Evaluation. She has over twenty years' experience in agricultural research on forage agronomy, conservation and utilisation, and forage seed production and marketing, over five years in banking and agribusiness and three years of humanitarian and rural development work.
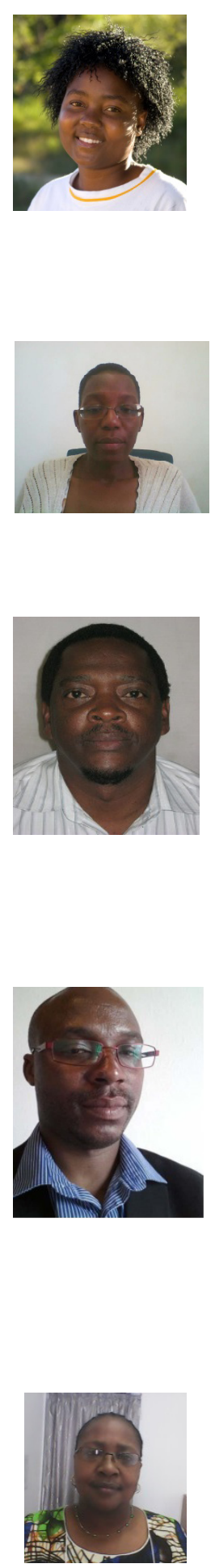